\title{
lleoscopy: when ileal evaluation is not mandatory during colonoscopy
}

\author{
Leticia ROSEVICS and Odery RAMOS JÚNIOR
}

Received: 30 August 2020 Accepted: 2 February 2021

ABSTRACT - Background - Ileitis is defined as ileal inflammation, with several etiologies, including inflammatory bowel disease (IBD), and can be evaluated during the colonoscopy exam, but its mandatory evaluation is discussed, because of few diagnosis and procedure time. Objective - This study aims to evaluate the correlation of colonoscopic ileitis with the clinical presentation, in order to identify the cases where ileal examination is mandatory. Methods - A retrospective, cross-sectional study was conducted between 2013 and 2017. The examination report, indications for colonoscopy, and medical records were evaluated in order to identify whether the colonoscopic findings were clinically significant. Patients over 18 years of age who had undergone ileoscopy were included, whereas patients below 18 years of age, those with previous intestinal resections, and repeated examinations of the same patient in the study period were excluded. The estimated association measure was the odds ratio with $95 \%$ confidence intervals. $P$-values $<0.05$ indicated statistical significance. Results - A total of 3382 cases were included. Among these participants, $64.5 \%$ were females and the average age was $56.9 \pm 13.1$ years ( $18-89$ years). Ileal alterations were observed in $5.3 \%$ of the patients, with $2.69 \%$ being clinically significant between all patients, and $0.96 \%$ excluding those with IBD. There was a positive correlation between the ileitis findings and IBD control examinations and a negative correlation in screening and change in bowel habit indications. Among the indications with ileitis clinically significant, IBD control still had a positive correlation, 'diarrhea' and 'others' did not show a statistical significance, and all other indications presented a negative correlation for ileal assessment. Conclusion - Ileal evaluation in only mandatory in IBD control. When the main colonoscopy objective is detecting colonic neoplasms, ileoscopy is unnecessary.

Keywords - Colonoscopy; ileitis; inflammatory bowel disease; cancer screening; colonic polyp.

\section{INTRODUCTION}

Ileitis is defined as an inflammation of the ileum, which is the portion of the small intestine that is evaluated during colonoscopy ${ }^{(1)}$.

Although Crohn's disease is commonly associated with ileitis, various differential diagnoses must be considered with its presentation. These can be divided into the following etiologic groups ${ }^{(1-5)}$ :

1. Infectious causes: tuberculosis, Yersinia, Salmonella, Clostridioides difficile, typhlitis, Mycobacterium avium, actinomycosis, histoplasmosis, Anisakiasis, and cytomegalovirus.

2. Spondyloarthropathy: related to ankylosing spondylitis, reactive arthritis, psoriasis, and undifferentiated spondyloarthropathy.

3. Vasculitis: systemic lupus erythematosus, cutaneous polyarteritis nodosa, and Henoch-Schönlein purpura.

4. Ischemia: cause of the splanchnic hypoperfusion in nonocclusive mesenteric ischemia.

5. Neoplasms: represented by adenocarcinoma, lymphoma, and carcinoid tumor, in addition to the alterations present in patients with familial adenomatous polyposis, hereditary non-polypoid colorectal cancer, and Peutz-Jeghers syndrome.

6. Drug-induced: related to non-steroidal anti-inflammatories, oral potassium chloride tablets, oral hormonal contraceptives, ergotamine, digoxin, and hydrochlorothiazide with enteric potassium coating.
7. Systemic diseases: eosinophilic enteritis, amyloidosis, sarcoidosis, endometriosis, and systemic mastocytosis.

8. Lymphoid hyperplasia: Ileitis of uncertain significance (more prevalent in children).

9. Immunoglobulin-G4-related: there are reports of ileal manifestations, including those mimicking ileocecal neoplasia by intestinal subocclusion ${ }^{(6,7)}$.

The assessment of the ileum is part of complete colonoscopy, but because of the difficulty in its implementation, longer examination time, and the low need for completion of diagnosis, its obligation in all examinations is questioned ${ }^{(3,8)}$ and it would rather be of greater relevance in the investigation of symptomatic patients $^{(9)}$. The need to enter the ileum, perform biopsy if alterations are observed, and the clinical significance of the findings is under discussion. Thus, the objective of this study is to evaluate the correlation of colonoscopy ileitis with the clinic exam indication, in order to identify cases where ileal evaluation could be mandatory.

\section{METHODS}

This study was conducted retrospectively using the data of colonoscopy examinations performed at the Clinical Hospital Complex of the Federal University of Paraná, a Brazilian tertiary public university hospital, between 2013 and 2017.

Colonoscopy indications and reports of the selected patients 
were evaluated. This study included patients over 18 years of age who had undergone ileoscopy. Patients below 18 years, those with no ileal evaluation or undergone surgical manipulation with total or partial resection of the small and/or large intestines, as well as repeated examinations of the same patient during the study period were excluded.

The indications of colonoscopy were categorized as follows: abdominal pain, follow-up of patients with inflammatory bowel disease (IBD), bleeding from the gastrointestinal tract, constipation, diarrhea, chronic anemia, weight loss/ consumptive disease, change in bowel habit, control of neoplasia of the gastrointestinal tract, control of colonic polyps, colorectal cancer screening, and others.

In order to assess whether the ileitis was clinically relevant, a review of the medical records of patients was performed to evaluate their follow-up and outcomes. Ileitis indicated as a diagnostic or therapeutic change was considered clinically significant.

The results obtained in the study were represented as mean, standard deviation, minimum and maximum values (for age), or by frequencies and percentages (categorical variables). The association between the clinical presentation and the likelihood of the presence of ileitis (or clinical significance) was analyzed using the Fisher's exact test or by adjusting logistic regression models (univariate and multivariate analysis). After the adjustment of the models, the Wald test was used to assess the significance of the variables. The measure of association estimated was odds ratios with $95 \%$ confidence intervals. $P$-values $<0.05$ indicated statistical significance. The data were analyzed using the computer program Stata/SE version 14.1 (Stata Corp. LP, USA).

The study was approved by the local Ethics Committee.

\section{RESULTS}

From 2013 to 2017,5833 colonoscopies were performed at this hospital. Of these, 3382 examinations were included in the study, with exclusions indicated in FIGURE 1. Among those who had not ileal evaluation: $469(47.52 \%)$ do not have any justification in the exam description, $225(22.8 \%)$ had no appropriated bowel preparation, $120(12.16 \%)$ had technical difficulties, $93(9.42 \%)$ colon or ileocecal valve stenosis and $80(8.10 \%)$ other reasons.

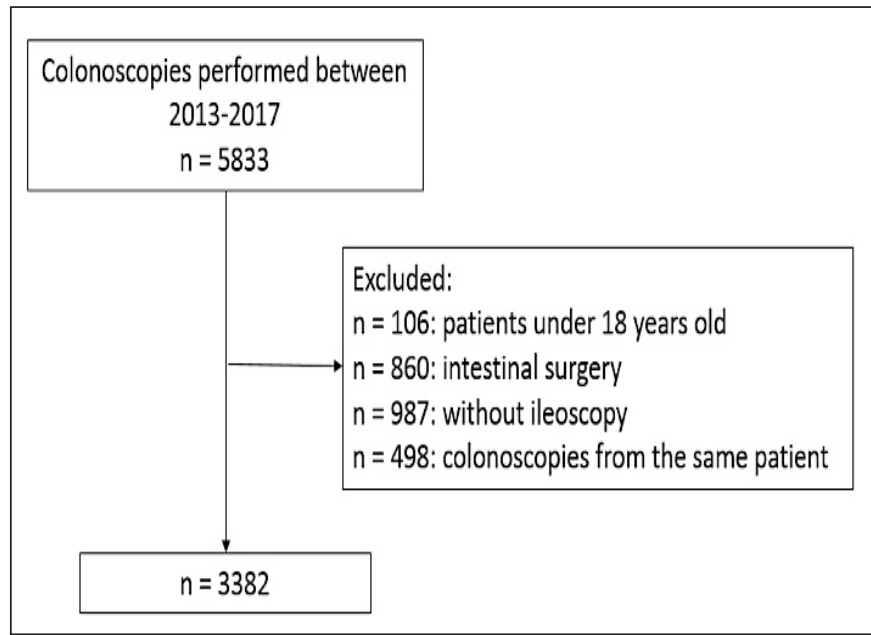

FIGURE 1. Description of the study sample, excluding patients younger than 18 years old, those with surgical intestinal manipulation, those without ileoscopy, and repeated examinations in the same patient.
The demographic profile of the patients revealed $64.5 \%$ female patients and an average age of $56.9 \pm 13.1$ years (18-89 years). The main indications of examinations were bleeding from the gastrointestinal tract and screening, as presented in TABLE 1 . The same patient could have more than one indication, excluding the screening of asymptomatic patients and those being controlled for IBD, who could have diarrhea, bleeding, and weight loss.

A total of 179 cases of ileitis were found (5.3\% of the patients), of which $50.84 \%$ had clinically significant ileitis. After excluding the patients who were examined for control of IBD where the evaluation of the ileum is mandatory, 118 patients remained and the ileal examination was clinically significant in $30(25.42 \%)$.

The diagnostics found in the 30 patients who did not have IBD were: 16 diagnostic tests of IBD, four graft versus host disease (GVHD), two ileitis due to cytomegalovirus, one carcinoid tumors, two ileitis related to spondyloarthropathy, one ileitis associated with vasculitis (Churg Strauss syndrome), one eosinophilic ileocolitis, one caused by Ebstein-Barr virus, one drug-related (non-steroidal anti-inflammatory) and one GVHD with cytomegalovirus infection.

The main macroscopic findings during endoscopy are shown in TABLE 2.

To evaluate the presence of ileitis and its clinical indications, the results are presented in TABLE 1 and demonstrate the importance according to the indications with respect to the ileitis cases $(n=179)$ and those with clinical significance $(n=91)$. Among all patients, the indication for control of IBD was statistically significant as a risk factor for ileitis, while screening and change in bowel habit were protective factors. When analysis was performed only for clinically significant examinations, it was observed that the control of IBD remains a predictive factor to detect ileal alterations, while all other indications, except for 'diarrhea' and 'others', revealed a negative correlation.

\section{DISCUSSION}

In the present study, ileal alterations were found in $5.3 \%$ of patients, but when we exclude those with IBD the alterations where found in $3.79 \%$. The presence of ileitis reported in the literature is similar, varying from $1-5 \%{ }^{(3,9-13)}$. Among the total number of ileitis in this study, only $91(2.69 \%)$ patients showed clinical relevance, indicating a diagnosis or change of treatment, of these $30(0.96 \%)$ in patients without IBD. This data was also concurrent with the literature, which reports that ileal examination helped in the diagnosis in $1.0-7.2 \%$ of routine colonoscopies ${ }^{(8,10,11,14,15)}$.

According to the guidelines of IBD, ileal examination is an important part of the colonoscopy in these patients. In our assessment of both the general and clinically significant samples, ileal evaluation showed statistical significance in these patients, providing an 18.5 - 46.4 times greater likelihood of finding ileal alterations in them. In 1998, in order to justify ileal examination in patients with IBD, Geboes retrospectively evaluated the ileoscopies of patients with IBD versus those controlled for polyps as the control group, demonstrating that 123 of the 257 patients with IBD had ileitis, while the control group had none ${ }^{(16)}$.

In all examinations, including the clinically significant ones, ileal evaluation in patients undergoing screening and change in the bowel habit showed with statistical significance that ileoscopy in these clinical indications is unnecessary. In 2006, Yoong et al. evaluated 2149 colonoscopies and concluded that the time spent in performing 
TABLE 1. Comparison between endoscopic ileitis, endoscopic clinical relevant ileitis, and clinical indications for the examination.

\begin{tabular}{|c|c|c|c|c|c|}
\hline Indication & $\mathrm{n}$ & With endoscopic ileitis & Endoscopic clinical relevant ileitis & $P$ & OR $(95 \% \mathrm{CI})$ \\
\hline Abdominal pain & 486 & $21(4.3)$ & $5(1)$ & $\begin{array}{l}0.302 \\
0.019\end{array}$ & $\begin{array}{l}0.78(0.49-1.25) \\
0.34(0.14-0.84)\end{array}$ \\
\hline Bleeding & 706 & $27(3.8)$ & $9(1.3)$ & $\begin{array}{l}0.052 \\
0.012\end{array}$ & $\begin{array}{l}0.66(0.43-1.00) \\
0.41(0.20-0.82)\end{array}$ \\
\hline Anemia & 278 & $13(4.7)$ & $1(0.4)$ & $\begin{array}{l}0.632 \\
0.037\end{array}$ & $\begin{array}{l}0.86(0.49-1.55) \\
0.12(0.02-0.88)\end{array}$ \\
\hline Diarrhea & 421 & $27(6.4)$ & $15(3.6)$ & $\begin{array}{l}0.273 \\
0.233\end{array}$ & $\begin{array}{l}1.27(0.83-1.93) \\
1.41(0.80-2.47)\end{array}$ \\
\hline Weight loss & 420 & $14(3.3)$ & $3(0.7)$ & $\begin{array}{l}0.058 \\
0.014\end{array}$ & $\begin{array}{l}0.58(0.34-1.02) \\
0.24(0.07-0.75)\end{array}$ \\
\hline Cancer control & 29 & $1(3.5)$ & $0(0)$ & $\begin{array}{l}0.659 \\
0.008\end{array}$ & $\begin{array}{c}0.64(0.09-4.71) \\
-\end{array}$ \\
\hline Change in bowel habit & 246 & $4(1.6)$ & $0(0)$ & $\begin{array}{l}0.012 \\
0.007\end{array}$ & $\begin{array}{c}0.28(0.10-0.76) \\
-\end{array}$ \\
\hline Control of IBD & 273 & $61(22.3)$ & $61(22.3)$ & $\begin{array}{l}<0.001 \\
<0.001\end{array}$ & $\begin{array}{l}7.29(5.20-10.2) \\
29.3(18.5-46.4)\end{array}$ \\
\hline Screening & 638 & $12(1.9)$ & $2(0.3)$ & $\begin{array}{l}<0.001 \\
0.001\end{array}$ & $\begin{array}{l}0.30(0.16-0.53) \\
0.09(0.02-0.38)\end{array}$ \\
\hline Others & 192 & $12(6.3)$ & $2(1.1)$ & $\begin{array}{l}0.542 \\
0.163\end{array}$ & $\begin{array}{l}1.21(0.66-2.21) \\
0.37(0.09-1.50)\end{array}$ \\
\hline
\end{tabular}

IBD: inflammatory bowel disease; OR: odds ratio; CI: confidence interval.

TABLE 2. Macroscopic ileal findings with colonoscopy.

\begin{tabular}{lc}
\hline Lesion & $\mathbf{n}$ \\
\hline None & 3203 \\
Erosion & 42 \\
Ulcer & 40 \\
Lymphoid hyperplasia & 29 \\
Others & 17 \\
Enanthema & 11 \\
Erosion and enanthema & 8 \\
Polyp & 6 \\
Ulcer and other & 4 \\
Ulcer and erosion & 4 \\
Ulcer and enanthema & 3 \\
Erosion, polyps, and others & 3 \\
Erosion and others & 3 \\
Enanthema and others & 2 \\
Ulcer, enanthema, and others & 2 \\
Ulcer and lymphoid hyperplasia & 1 \\
Lymphoid hyperplasia and polyps & 1 \\
Ulcer and polyp & 1 \\
Lymphoid hyperplasia, erosion, and enanthema & 1 \\
Ulcer, erosion, enanthema, and others & 1 \\
Total & 3382 \\
\hline
\end{tabular}

the examination in asymptomatic patients would be equivalent to the time required to complete over 2000 colonoscopies per year in the English health system ${ }^{(8)}$, an information with significant impact in public health care, particularly in developing countries such as Brazil. In 2008, Kennedy evaluated 6408 colonoscopies performed by screening and categorizing patients as symptomatic and asymptomatic, and only $1 \%$ of colonoscopies showed macroscopic changes and $0.3 \%$ showed anatomopathological abnormalities ${ }^{(11)}$.

In order to carry out an analysis of the benefit of systematic ileal examinations, the anatomopathological and anatomoclinical correlations of detecting ileitis are important, as well as the relevance of these findings in the diagnostic clarification. Some data corroborate ileal evaluation for certain indications. Jeong et al. evaluated 3415 ileoscopies retrospectively and observed that $91.2 \%$ of the biopsies were non-specific, but clinical relevance was found in examinations presenting signs of pain in the right iliac fossa as compared to screening patients ${ }^{(12)}$. In 2009, Castano published data from a retrospective study of 1467 patients, showing statistical significance in patients with a history of consumption of non-steroidal anti-inflammatories and presence of HIV, as well as indications of abdominal pain, diarrhea and follow-up of IBD, but without clarifying whether there was a clinical correlation in the changes found ${ }^{(17)}$. In 2018, Meral et al. evaluated 1032 ileoscopies and observed a statistical significance in finding ileal changes in symptomatic patients, when comparing symptomatic with asymptomatic patients (screening) ${ }^{(18)}$. In our study, considering only the cases with clinical significance, indications of abdominal pain, bleeding, anemia, consumptive syndrome/weight loss, and control of cancer or polyps do not require ileoscopy. It was observed that 
there are not enough clinically statistically significant ileal changes to indicate a mandatory ileal examination in these patients. It is important to note that in all these indications, the main need for colonoscopic evaluation is detecting neoplasms, which could be the main cause of the mentioned symptoms, and the control of polyps or neoplasms. Thus, as in screening tests and changes in bowel habits, the final indication of an invasive test, such as colonoscopy, is detecting colonic neoplasms.

In patients undergoing investigations for chronic diarrhea, a significant histopathological alteration was found in the literature in $9-19 \%$ patients $^{(19-23)}$. In the present study, this was the only indication that did not show statistical significance in all patients and in those showing clinical relevance, indicating that the non-mandatory ileal examination still needs to be discussed in these patients.

\section{CONCLUSION}

This study had few limitations such as the sample size, bias of the population studied (single center of a tertiary hospital sample), and retrospective design. Moreover, some patients presented more than one indication for the examination, and this factor could have compromised part of the analysis of the indications. However, we sought to reduce these limitations by withdrawing the examination of patients with intestinal surgical manipulation, as well as defin- ing cases providing diagnosis or change of treatment as clinically significant examinations. This differed from the previous studies that included cases in which ileitis was a reason for further examinations, because in this case it was possibly an iatrogenic disease. Moreover, the other studies with similar scope compared cases and controls, in which cases were symptomatic patients and controls were screening patients. In contrast, we evaluated patients with the same indications among themselves, because they presented the same risk of having ileal alterations theoretically.

Thus, the study concludes that there is a need of ileoscopy in patients with IBD, but no need of ileal evaluation in screening or in cases where the main intent is to find neoplasms. This can optimize the time of examination for a proper evaluation of the colonic mucosa to find polyps and lesions. For ileal examination in patients with chronic diarrhea, further studies are needed.

\section{Authors' contribution}

Rosevics L designed the research study, performed the research and wrote the paper. Ramos Júnior $\mathrm{O}$ designed the research study and wrote the paper.

\section{Orcid}

Leticia Rosevics: 0000-0001-7307-1895.

Odery Ramos Júnior: 0000-0002-9730-6860.

Rosevics L, Ramos Júnior O. Ileoscopia: quando a avaliação ileal não é mandatória durante a colonoscopia. Arq Gastroenterol. 2021;58(2):175-9.

RESUMO - Contexto - Ileíte é definida como inflamação ileal, com diversas etiologias, incluindo doença inflamatória intestinal (DII), e pode ser avaliada durante o exame de colonoscopia, mas sua avaliação obrigatória é discutida, devido aos poucos diagnósticos e tempo de procedimento. Objetivo - O objetivo deste estudo é avaliar a correlação da ileíte colonoscópica com a apresentação clínica, a fim de identificar os casos em que o exame ileal é obrigatório. Métodos - Foi realizado um estudo transversal retrospectivo entre 2013 e 2017. O laudo do exame, as indicações para colonoscopia e os prontuários médicos foram avaliados para identificar se os achados colonoscópicos eram clinicamente significativos. Pacientes maiores de 18 anos submetidos à ileoscopia foram incluídos, enquanto pacientes menores de 18 anos, aqueles com resseç̧ões intestinais prévias e exames repetidos do mesmo paciente no período de estudo foram excluídos. A medida de associação estimada foi o odds ratio com intervalos de confiança de $95 \%$. Valores de $P<0,05$ indicaram significância estatística. Resultados - Foram incluídos 3382 casos. Desses, 64,5\% eram mulheres e a média de idade foi de 56,9 $\pm 13,1$ anos (18-89 anos). Alterações ileais foram observadas em 5,3\% dos pacientes, sendo 2,69\% clinicamente significativos entre todos os pacientes e $0,96 \%$ excluindo aqueles com DII. Houve uma correlação positiva entre os achados de ileíte e exames de controle de DII e uma correlação negativa no rastreamento e alteração de hábito intestinal. Entre as indicações com ileíte clinicamente significativa, o controle de DII ainda teve uma correlação positiva, 'diarreia' e 'outros' não apresentaram significância estatística, e todas as outras indicações apresentaram correlação negativa para avaliação ileal. Conclusão - A avaliação ileal é obrigatória apenas no controle de DII. Quando o objetivo principal da colonoscopia é detectar neoplasias colônicas, a ileoscopia é desnecessária.

Palavras-chave - Colonoscopia; ileíte; doença inflamatória intestinal; rastreamento do câncer; pólipo colônico.

\section{REFERENCES}

1. Dilauro S, Crum-Cianflone NF. Ileitis: when it is not Crohn's disease. Curr Gastroenterol Rep. 2010 Aug;12(4):249-58.

2. Bojic D, Markovic S. Terminal ileitis is not always Crohn's disease. Ann Gastroenterol. 2011;24:271-5.

3. Emami MH, Behbahan IS, Zade HD, Daneshgar H. New interpretation for diagnostic yield of ileoscopy: A prospective study and a brief review. J Res Med Sci. 2009; 14:157-63

4. Nagasako K, Yazawa C, Takemoto T. Biopsy of the terminal ileum. Gastrointest Endosc. 1972;19(1):7-10. [Internet]. Available from: http://dx.doi.org/10.1016/ S0016-5107(72)73931-0

5. Sands BE. From symptom to diagnosis: Clinical distinctions among various forms of intestinal inflammation. Gastroenterology. 2004;126:1518-32.

6. Fujita K, Naganuma M, Saito E, Suzuki S, Araki A, Negi M, et al. Histologically confirmed IgG4-related small intestinal lesions diagnosed via double balloon enteroscopy. Dig Dis Sci. 2012;57:3303-6.
7. Hiyoshi Y, Oki E, Zaitsu Y, Ando K, Ito S, Saeki H, et al. IgG4-related disease of the ileocecal region mimicking malignancy: A case report. Int J Surg Case Rep [Internet]. 2014;5(10):669-72. Available at: http://dx.doi.org/10.1016/j.ijscr.2014.08.003

8. Yoong KKY, Heymann T. It is not worthwhile to perform ileoscopy on all patients. Surg Endosc Other Interv Tech. 2006;20:809-11.

9. Akere A, Otegbayo J, Tejan E. Terminal ileum intubation during colonoscopy: Should it be routinely performed on all patients? Trop J Med Res. 2017;20:66.

10. Cherian S, Singh P. Is routine ileoscopy useful? An observational study of procedure times, diagnostic yield, and learning curve. Am J Gastroenterol. 2004:99:2324-9.

11. Kennedy G, Larson D, Wolff B, Winter D, Petersen B, Larson M. Routine ileal intubation during screening colonoscopy: A useful maneuver? Surg Endosc Other Interv Tech. 2008;22:2606-8.

12. Jeong SH, Lee KJ, Kim YB, Kwon HC, Sin SJ, Chung JY. Diagnostic value of terminal ileum intubation during colonoscopy. J Gastroenterol Hepatol. 2008;23:51-5. 
13. Wijewantha HS, De Silva AP, Niriella MA, Wijesinghe N, Waraketiya P, Kumarasena RS, et al. Usefulness of routine terminal ileoscopy and biopsy during colonoscopy in a tropical setting: A retrospective record-based study. Gastroenterol Res Pract. 2014;2014:343849.

14. Kundrotas LW, Clement DJ, Kubik CM, Robinson AB, Wolfe PA. A prospective evaluation of successful terminal ileum intubation during routine colonoscopy. Gastrointest Endosc. 1994;40:544-6.

15. Zwas FR, Bonheim NA, Berken CA, Gray S. Diagnostic yield of routine ileoscopy. Am J Gastroenterol. 1995;90:1441-3.

16. Geboes K. Is Ileoscopy With Biopsy Worthwhile in Patients Presenting With Symptoms of Inflammatory Bowel Disease? Am J Gastroenterol. 1998;93:201-6.

17. Rodrigo Castano, Juan Puerta, José Restrepo, Jaime Escoba, Oscar Alvarez, Edilberto Nuñez, et al. Diagnostic value of routine ileoscopy. Am J Gastroenterol 2009;104(S503).
18. Meral M, Bengi G, Kayahan H, Akarsu M, Soytürk M, Topalak Ö, et al. Is ileocecal valve intubation essential for routine colonoscopic examination? Eur J Gastroenterol Hepatol. 2018;30:432-7.

19. Petre S, Shah IA, Gilani N. Review article: Gastrointestinal amyloidosis - clinical features, diagnosis and therapy. Aliment Pharmacol Ther. 2008;27:1006-16.

20. Yusoff IF, Ormonde DG, Hoffman NE. Routine colonic mucosal biopsy and ileoscopy increases diagnostic yield in patients undergoing colonoscopy for diarrhea. J Gastroenterol Hepatol. 2002;17:276-80.

21. Marshall JB, Barthel JS. The frequency of total colonoscopy and terminal ileal intubation in the 1990s. Gastrointest Endosc. 1993;39:518-20.

22. Fine KD, Seidel RH, Do K. The prevalence, anatomic distribution, and diagnosis of colonic causes of chronic diarrhea. Gastrointest Endosc. 2000;51:318-26.

23. Hamid S, Jafri W, Abbas Z, Shah H, Abid S, Sheikh H, et al. Microscopic colitis: A diagnosis to consider. J Pak Med Assoc. 1993;43:203-5. 